\title{
Kinetic modeling of sugarcane juice clarification by ozonation in batch reactor with ozone saturation control
}

\author{
Ricardo BERNARDI ${ }^{1 \star}$, Luiz Mario de Matos JORGE² (D), Paulo Roberto PARAÍSO²
}

\begin{abstract}
This work presents the mathematical modeling of clarification kinetics of the sugarcane juice by ozonation in batch reactor considering the reaction occurs homogeneously and ozone saturation in the juice is guaranteed. The sugarcane juice color was considered proportional to the light absorbance at wavelength $\lambda=420 \mathrm{\eta m}$, according to the International Unit specified by ICUMSA - International Commission for Uniform Methods of Sugar Analysis. The model equation coefficients were obtained numerically, using the $\mathrm{MATLAB}^{\circledR}$ software, based on the experimental absorbance as a function of time, obtained for three different temperatures of the juice. The obtained results were so much satisfactory and led to the conclusion that mathematical model represents well the kinetics of clarification in the proposed conditions.
\end{abstract}

Keywords: ozone; sugarcane juice; kinetic of clarification; modeling, control.

Practical Application: By using the mathematical model presented in this manuscript, industry could provide ozone saturation control in sugarcane clarification proccess by ozonation. In this way, sugarcane juice would be saturated with ozone all time, without ozone wasting, consequently, saving energy.

\section{Introduction}

After being target of dispute for centuries, the sugarcane found its ideal place in Brazil. Introduced in colonial period, sugarcane becomes one of the main brazilian economy cultures. During the empire, it is estimated that the sugarcane in Brazil yielded five times more profits than all other agricultural products for export. Brazil is the world's largest producer of sugarcane and largest producer and exporter of sugar in the world (Biosev, 2014).

The high quality sugar production occurs through sugarcane juice clarification. The traditional clarification process is characterized by a step known as sulfitation, which releases sulfur residues harmful to human health and the environment (Silva, 2008). The presence residue of sulfur dioxide restricts Brazilian exports of white sugar because many importing countries are avoiding buy products with the presence of this substance (Ribeiro, 2009).

The Food and Agriculture Organization of United Nations (FAO) and World Health Organization (WHO), admits a maximum of 15 milligrams of $\mathrm{SO}_{2}$ per kilogram of white sugar for direct consumption, but there are international movements in order to reduce this limit. Brazil also has a law project called PL6639/09, which promises reduce to 1 milligram of SO2 per kilogram. Furthermore, financial institutions and constitutional funds will be prohibited from granting credit to industries that use sulfur to produce white sugar (Ribeiro, 2009).

Throughout history, various alternative processes were studied in order to replace the sulfitation as clarification process for sugarcane juice. Currently we can cite numerous published scientific papers related to the theme, such as: bicarbonation (Araujo, 2007), carbonation (Hamerski, 2009), cross-flow filtration (Armoa, 2012), use of accelerated electrons (Lima, 2012) among others. In this way, an inexpensive alternative to the replacement of the sulfur in the clarification process for sugarcane juice would be ozonation. The method consists of inject ozone directly into the inlet pipe column or clarification tower. Besides to avoid using of raw materials does not require major changes in the physical structure present today in the mills (Silton, 2007).

Ozone is an agent with high oxidation and disinfection power. Compared to chlorine, it is about 10 times more disinfectant and 3000 times faster in inactivation of bacteria (Armaroli, 2007). Due to the high ozone instability in most of its applications, it is generated locally through generators. Ozone generation can be given by Electrolysis, Ultra-Violet or Corona Discharge. We opted for studying the clarification of sugarcane juice by ozonation by believing that it is a promising alternative for the replacement of the sulfitation process. Moreover, there are still no relevant publications related to this theme and the model presented in this paper may also be used in other applications of clarification by ozonation in batch reactors.

\section{Metodology}

\subsection{Experimental data}

Collections of experimental data of absorbance versus time were essential for determining the coefficients from the mathematical model proposed in this article. For that, three 
clarification assays were performed for temperatures of: $\mathrm{T}_{1}=25^{\circ} \mathrm{C}$, $\mathrm{T}_{2}=35^{\circ} \mathrm{C}$ and $\mathrm{T}_{3}=45^{\circ} \mathrm{C}$. The temperature range was chosen so the sugarcane juice did not need to be heated in a possible industrial use of the process. This would avoid surplus costs with heat sources because most places in the country are within this range. A clarification system diagram used in the tests can be seen in Figure 1.

A corona generator was used to produce the ozone during the experimental data col- lection and storage. The air leak through the ozone generator reactor was limited and set to $7 \mathrm{~L} / \mathrm{min}$ and the generator voltage was controlled by a closed loop control system in order to keep the sugarcane juice solution saturated without providing excess ozone. During the process, the temperature of the juice was kept constant by a sealed resistance controlled by a dimmer. A peristaltic pump was used to pump juice through the absorbance sensor. The temperature of the juice, the excess of ozone, the absorbance of the juice and the reactor voltage were collected and stored to a notebook database every 5 seconds. At the end of the tests, the data was exported to “.csv" files and used in MATLAB ${ }^{\circledR}$ software to fit the coefficients of mathematical model proposed. A fume hood was used in all tests to provide safety.

\subsection{Mathematical modeling}

The mathematical model was developed with clarification reaction occurring in a batch reactor. The reaction was considered occurring homogeneously and given by Equation 1 .

$\mathrm{P}+\mathrm{O}_{3} \rightarrow \mathrm{C}$

where: $\mathrm{P}=$ Pigmented Solution; $\mathrm{C}=$ Clarified Solution.

Considering an empirical reaction rate given by Equation 2 (Fogler, 2008).

$-r_{p}=k_{p} \cdot C_{p}^{\alpha} \cdot C_{O_{3}}^{\beta}$ where: $\mathrm{r}_{\mathrm{p}}=$ Pigments reaction rate; $\mathrm{k}_{\mathrm{p}}=$ Reaction rate constant; $\mathrm{C}_{\mathrm{p}}=$ Pigments concentration; $\mathrm{C}_{\mathrm{O} 3}^{\mathrm{p}}=$ Ozone concentration; $\alpha=$ Pigments reaction order; $\beta=$ Ozone reaction order.

The mass balance for the pigments in the reactor is given by Equation 3.

$A=E-S+G-C$

where: $\mathrm{A}=$ Mass rate of pigments accumulated in the reactor; $\mathrm{E}=$ Mass rate of pigments entering in the reactor; $\mathrm{S}=$ Mass rate of pigments leaving the reactor; $\mathrm{G}=$ Mass rate of pigments produced in the reactor; $\mathrm{C}=$ Mass rate of pigments consumed in the reactor.

Knowing that does not enter $(\mathrm{E}=0)$ or leave $(\mathrm{S}=0)$ pigments in the reactor and assuming that no pigment is produced $(G=0)$ inside the reactor, the mass balance of pigments is now represented by Equation 4.

$A=-C$

Rewriting Equation 4, we obtain the Equation 5.

$\frac{d C_{p}}{d t}=r_{p}$

Substituting Equation 2 in 5 obtains the Equation 6.

$\frac{d C_{p}}{d t}=-k_{p} \cdot C_{p}^{\alpha} \cdot C_{O_{3}}^{\beta}$

Whereas the flow of ozone is high enough that the ozone concentration in the reactor keep saturated, it can be assumed that it is constant like Equation 7.

$C_{O_{3}}^{\beta}=k_{\text {sat }}$

where: $\mathrm{k}_{\text {sat }}=$ Ozone saturation constant.

Therefore, substituting Equation 7 in Equation 6, will result in Equation 8.

$\frac{d C_{p}}{d t}=-k_{p} \cdot k_{s a t} \cdot C_{p}^{\alpha}$

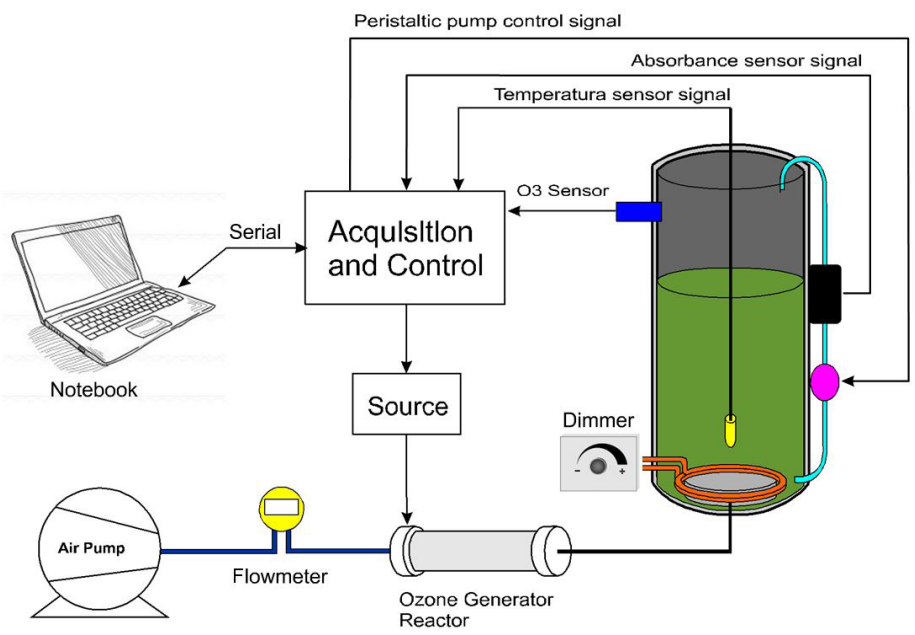

Figure 1. Batch Reactor Clarification System with Ozone Saturation Control. 
Still, assuming that the concentration of pigment is proportional to absorbance at the wavelength of $\lambda=420 \eta \mathrm{m}$, according to the International Unit specified by ICUMSA, we have Equation 9.

$C_{p}=k_{a} \cdot A_{\lambda}$

where: $\mathrm{A} \lambda=$ Absorbance at the wavelength of $\lambda=420 \eta \mathrm{m}$; $\mathrm{ka}=$ Proportional Constant.

Substituting Equation 9 in Equation 8, we obtain Equation 10.

$k_{a} \cdot \frac{d A_{\lambda}}{d t}=-k_{p} \cdot k_{s a t} \cdot k_{a}^{\alpha} \cdot A_{\lambda}^{\alpha}$

Dividing both sides of Equation 10 by $\mathrm{k}_{\mathrm{a}}$, will result in Equation 11.

$\frac{d A_{\lambda}}{d t}=-k_{p} \cdot k_{s a t} \cdot k_{a}^{\alpha-1} \cdot A_{\lambda}^{\alpha}$

Rewriting Equation 11, we obtain Equation 12.

$\frac{d A_{\lambda}}{A_{\lambda}^{\alpha}}=-k_{p} \cdot k_{s a t} \cdot k_{a}^{\alpha-1} \cdot d t$

The Equation 12 can have many different solutions. The solution with coefficients best fitted to empirical data was called BPJ (Bernardi-Paraíso-Jorge) Model.

\subsection{Coefficient fitting}

All coefficients from the mathematical model proposed in this work were obtained through MATLAB ${ }^{\circledR}$ software producing curves with Determination Coefficient $\left(\mathrm{R}^{2}>0.99\right)$ and Standard Error of the Estimate $\left(\mathrm{S}_{\mathrm{e}}{ }^{2}<0.01\right)$. The set of curves with best $\mathrm{R}^{2}$ and $\mathrm{S}_{\mathrm{e}}{ }^{2}$ were used to generalize the mathematic model through Arrhenius Equation. The best one was called BPJ Model.

The Global Average Error between absorbances calculated with BPJ Model and absorbances experimentally obtained were calculated by using the Equation 13 .

Global Average Error $=\frac{1}{N} \sum_{1}^{N} \frac{\left|A_{c}(n)-A_{e}(n)\right|}{A_{e}(n)} \cdot 100 \%$

where: $\mathrm{N}=$ Total number of samples; $\mathrm{A}_{c}(\mathrm{n})=$ Absorbances calculated by mathematical model for sample $n ; A_{e}(n)=$ Absorbance experimentally obtained for sample $\mathrm{n}$.

\section{Results and discussion}

\subsection{Experimental absorbance vs time}

Picture 2 shows absorbance vs time curves experimentally obtained for 3 temperatures of the sugarcane juice: $\mathrm{T}_{1}=25^{\circ} \mathrm{C}$ (blue), $\mathrm{T}_{2}=35^{\circ} \mathrm{C}$ (green) and $\mathrm{T}_{3}=45^{\circ} \mathrm{C}$ (red).

By analyzing the Figure 2 it is possible to note that the color of the sugarcane juice describes a decreasing exponential behavior and tend to stabilize in different values for each different temperature. This information meets one of the solutions of the Equation 12 when $a$ is equals to 1, that produces the Equation 14.
$A_{f}=\left(A_{i}-k_{1}\right) \cdot e^{-k^{\prime} \cdot\left(t_{f}-t_{i}\right)}+k_{1}$

where: $\mathrm{k}^{\prime}=$ Proportional constant $\left(\mathrm{k}^{\prime}=\mathrm{k}_{\mathrm{p}} \cdot \mathrm{k}_{\mathrm{o}}\right) ; \mathrm{k}_{1}=$ Arrhenius constant; $A_{f}=$ Absorbance at the ending of time interval; $A_{i}=$ Absorbance at the beginning of time interval; $t_{f}=$ Time at the ending of interval; $t_{i}=$ Time at the beginning of interval.

\subsection{BPJ model}

The best fitted coefficients of the Equation 14 produced the set curves showed in the Figure 3 - picture on the left side. The graphic shows the same absorbances experimentally obtained as showed in the Picture $2-\mathrm{T}_{1}=25^{\circ} \mathrm{C}$ (blue), $\mathrm{T}_{2}=35^{\circ} \mathrm{C}$ (green) and $\mathrm{T}_{3}=45^{\circ} \mathrm{C}$ (red) - associated with the curves (black) obtained by using BPJ Model. The picture on the right side shows an experimental vs calculated absorbance graphic that illustrate the error obtained for each sample. The diagonal (yellow) represents error equals to zero and the dashed lines (black) represents error equals to $5 \%$. The area between the 2 dashed lines represents errors less than 5\%. In this way it is possible to note that errors obtained with BPJ Model were less than 5\%.

By using Equation 13 it was possible to mensure the Global Average Error $=0.85 \%$ with sample with maximum error $=3.48 \%$. It is important to note that each experimental curve was produced using 480 samples, totalizing 1440 samples for the 3 temperatures involved. The BPJ Model could be seen in the Equation 15 where $\mathrm{k}_{1}$ is substituted by the Arrhenius coefficients.

$A_{f}=A_{0} \cdot e^{-k^{\prime} \cdot t}+C_{a} \cdot e^{-E_{a} / R \cdot T} \cdot\left(1-e^{-k^{\prime} \cdot t}\right)$

where: $\mathrm{k}^{\prime}=0.00146 ; \mathrm{C}_{\mathrm{a}}=0.161$ (Arrhenius constant); $\mathrm{E}_{\mathrm{a}}=-3269.1$ (Activation energy); $\mathrm{R}=8.314$ (Universal constant of ideal gases).

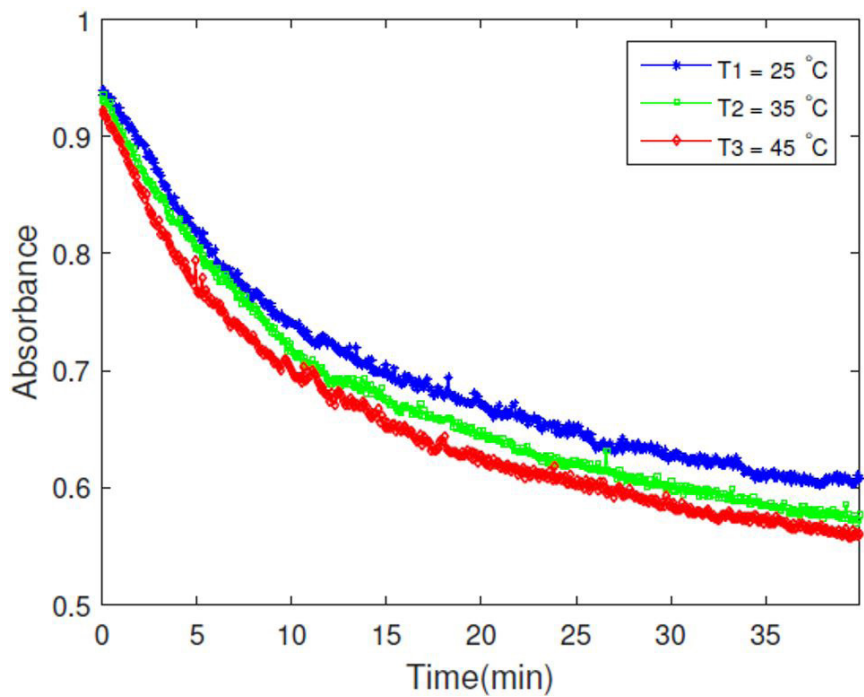

Figure 2. Absorbance vs Time for 3 different sugarcane juice temperatures. 

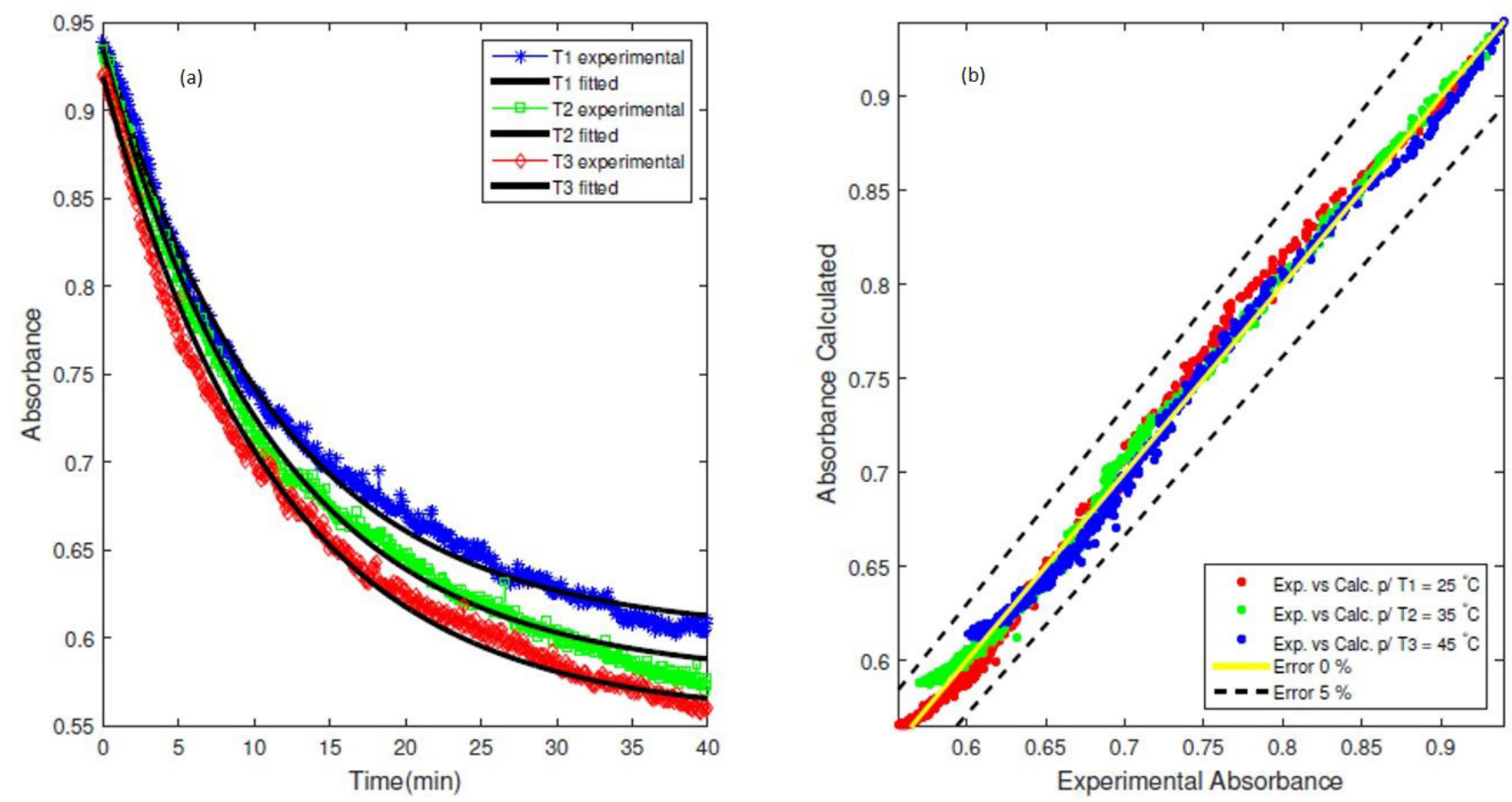

Figure 3. (a) Experimental Absorbance vs Time associated to BPJ Model Curves; (b) Absorbance Calculated vs Experimental Absorbance and Error Guide Lines.

\section{Conclusion}

The average global error of $0.85 \%$ was obtained by comparing 1440 samples of experimental absorbances in relation to the absorbances calculated by the BPJ Model. The high number of samples used and this small error percentage associated to them lead us to conclude that the mathematical model developed and presented in this work represents well the kinetics of sugarcane clarification when batch reactor is used and the saturation of ozone is guaranteed. The results of this work can be used by the sugar and alcohol industry to verify the viability of the use of the ozone in substitution of the process of sulfitation commonly used today.

\section{References}

Araujo, F. A. D. (2007). Processo de clarificação do caldo de cana pelo método da bicarbonatação. Recife: Ciências \& Tecnologia.

Armaroli, J. G. (2007). Nova abordagem de ozonizadores para tratamento de água de esgoto por descarga corona (Dissertação de mestrado). Universidade de São Paulo, São Carlos.

Armoa, M. (2012). Clarificação de caldo de cana-de-açúcar por filtração tangencial em membrana compósita titânia/sílica. Jaboticabal: Ciência e Tecnologia.
Biosev. (2014). Setor sucroalcooleiro. São Paulo. Retrieved from http:// ri.biosev.com/biosev/web/conteudo_pt.asp?idioma $=0 \& \operatorname{conta}=28$ \&tipo $=30884$

Fogler, H. S. (2008). Elementos de engenharia das reações químicas (3. ed.). Rio de Janeiro: LTC.

Hamerski, F. (2009). Estudo de variáveis no processo de carbonatação do caldo de cana-de-açúcar (Dissertação de mestrado). Universidade Federal do Paraná, Curitiba.

Lima, R. B. (2012). Processo de clarificação de caldo de cana-de-açúcar aplicando elétrons acelerados (Dissertação de mestrado). Universidade de São Paulo, São Paulo. http://dx.doi.org/10.11606/D.85.2012. tde-16012013-143923.

Ribeiro, P. (2009). PL-6639/09. Brasília: Câmara dos Deputados. Retrieved from http://www.camara.gov.br/proposicoesWeb/ficha detramitacao idProposicao $=464804$

Silton, R. N. C. (2007). Processo de clarificação do caldo de cana-de-açúcar por ozonização. PI 0505003-0 A. Rio de Janeiro: INPI.

Silva, R. B. (2008). Aplicação da produção mais limpa no processo de clarificação do caldo de cana para produção de açúcar. In Anais do $28^{\circ}$ Encontro Nacional de Engenharia de Produção. Rio de Janeiro: ABEPRO. 